\title{
THE SOCIOENVIRONMENTAL FUNCTION OF RURAL PROPERTY: BUILDING A NEW PROPOSAL FOR THE RESOLUTION OF LAND DISPUTES IN THE SOUTH OF THE STATE BAHIA, BRAZIL
}

\author{
Roberto Muhájir Rahnemay Rabbani \\ Professor of Law \\ Universidade Federal do Sul da Bahia (Brazil) \\ rabbani@csc.ufsb.edu.br \\ Gabriela Narezi \\ Professor of Agroecology \\ Universidade Federal do Sul da Bahia (Brazil) \\ gnarezi@gmail.com
}

\author{
Allívia Rouse Carregosa Rabbani \\ Professor and Researcher \\ alliviarouse@hotmail.com \\ Emilia Rahnemay Kohlman Rabbani \\ Professor of Civil Engineering \\ Pernambuco University (Brazil) \\ emilia.rabbani@upe.br
}

Bahia Federal Institute of Education, Science and Technology - IFBA (Brazil)

Fecha de recepción: 11 de junio de 2020 / Fecha de aceptación: 26 de octubre de 2020

ABSTRACT: Rich in natural resources, Brazil is a country of continental proportions facing major social problems, many of which linked to the unequal 
distribution of land. In this regard, much land in Brazil fails to meet the principles of rational and adequate use, in terms of productivity, preservation of the environment, and labor relations. This article outlines the legal framework governing the socioenvironmental function of property in Brazil and examines how the stakeholders in land disputes in the south of the State of Bahia have reached a peaceful consensual solution to conflicts. Based on this analysis, we present a model that can be applied to similar disputes. We conducted a review of relevant laws and judicial decisions and analyzed documents relating to disputes between the forestry company Veracel Celulose S.A. and family farmer associations between 2009 and 2016. Our findings show that, despite the normative base of the settlements is effectively grounded in the notion of the social function of property, absolutely no mention of the principle was made by the stakeholders and legal actors during the process or in the agreements: the solution came out as the result of a consensus reached by two stakeholders. This could therefore be said to be a case of "judicial redundancy", whereby the key underlying legal principles relating to the social function of property were fulfilled without resorting to the courts.

RESUMEN: Rico en recursos naturales, Brasil es un país de proporciones continentales que enfrenta grandes problemas sociales, muchos de los cuales están relacionados con la distribución desigual de la tierra. En este sentido, muchas tierras en Brasil no cumplen con los principios de uso racional y adecuado, en términos de productividad, preservación del medio ambiente y relaciones laborales. Este artículo describe el marco legal que rige la función socioambiental de la propiedad en Brasil y examina cómo las partes interesadas en disputas de tierras en el sur del Estado de Bahía han alcanzado una solución consensuada pacífica a los conflictos. Con base en este análisis, presentamos un modelo que puede aplicarse a disputas similares. Llevamos a cabo una revisión de las leyes y decisiones judiciales relevantes y analizamos documentos relacionados con disputas entre la empresa forestal Veracel Celulose SA y las asociaciones de agricultores familiares entre 2009 y 2016. Nuestros resultados muestran que, a pesar del hecho de que la base normativa de los asentamientos se basa efectivamente en la noción de la función social de la propiedad, las partes y los actores legales no mencionaron el principio durante el proceso o en 
los acuerdos: la solución surgió como resultado del consenso alcanzado por dos partes interesadas. Por lo tanto, podría decirse que se trata de un caso de "redundancia judicial", en virtud del cual los principios jurídicos subyacentes clave relacionados con la función social de la propiedad se cumplieron sin recurrir a los tribunales.

RESUM: Ric en recursos naturals, el Brasil és un país de proporcions continentals amb problemes socials importants, molts dels quals vinculats a la desigual distribució de la terra. En aquest sentit, molta terra del Brasil no compleix els principis d'ús racional i adequat, en termes de productivitat, preservació del medi ambient i relacions laborals. Aquest article descriu el marc legal que regula la funció socioambiental de la propietat al Brasil i examina com les parts interessades en disputes sobre terres al sud de l'Estat de Bahia han aconseguit una solució consensuada pacífica als conflictes. A partir d'aquesta anàlisi, presentem un model que es pot aplicar a disputes similars. Hem realitzat una revisió de les lleis i decisions judicials rellevants i analitzat documents relacionats amb les disputes entre l'empresa forestal Veracel Celulose SA i les associacions de ramaders familiars entre el 2009 i el 2016. Els nostres resultats mostren que, malgrat que la base normativa dels assentaments està fonamentada eficaçment. en la noció de la funció social de la propietat, no es va fer absolutament cap esment del principi per part i els agents legals durant el procés ni en els acords: la solució va sorgir com a resultat d'un consens assolit per dues parts interessades. Es podria dir, doncs, un cas de "redundància judicial", pel qual es van complir els principis legals fonamentals relatius a la funció social de la propietat sense recórrer als tribunals.

KEYWORDS: land disputes - rural property - the socioenvironmental function of property - land use - social justice.

PALABRAS CLAVE: disputas por la tierra - propiedad rural - la función socioambiental de la propiedad - uso de la tierra - justicia social.

PARAULES CLAU: disputes per la terra - propietat rural - la funció socioambiental de la propietat - ús de la terra - justícia social. 
SUMMARY: I. Introduction II. 2. The socioenvironmental function of property in Brazil - a legal framework 3. Land disputes and consensual resolutions in the south of Bahia: observations and reflections IV. Final considerations V. References.

\section{INTRODUCTION}

One of the main contributing factors to social injustice in Brazil is the unequal distribution of land, denying wok and sustenance to those who would otherwise be able to cultivate in these fields. The Constitution of the Federal Republic of Brazil of 1988 (CFRB) provides that property shall perform its social function. That is, the right to private property is limited by the Constitution in order to protect the public interest and ensure that land fulfills its social purpose. Within this perspective, drawing on the analysis of successful experiences in the south of the State of Bahia, this study explores the consensual resolution of rural land disputes and presents an alternative that can be applied to similar situations in other regions.

Within the panorama of Brazil's history and legal framework, the socioenvironmental function of property is one of the principles that resonate across land issues. In this regard, Article 5 of the Brazilian Constitution guarantees the right to property (section XXII), provided that the property performs its social function (section XXIII).

The Constitution goes on to describe the concept of the social function of property in Article 186: "The social function is met when rural property simultaneously complies with the following requirements, in accordance with the criteria and standards prescribed by law: I. rational and adequate use; II. adequate use of available natural resources and preservation of the environment; [...]". There is therefore an umbilical relationship between the environment, natural resources, and the social function of property. That is, the socioenvironmental element of property is intrinsic to land use.

Also intimately linked to the social function of property, Article 225 provides that everyone has the right to an ecologically balanced environment and that the government and the community have a duty to preserve the environment. In turn, 
like links in a chain, the environment is directly tied to quality of life and health enshrined as fundamental rights in Article 5. Thus, it can be seen that the social function of property is not only "social", but also environmental and economic, at the service of the community, and, more particularly, existential, being tied to the preservation of species, including human beings.

Within this perspective - which has other infraconstitutional ramifications, for example, in the Civil Code and sparse normative instruments such as the 1964 Land Statute, 2001 Cities Statute, and 2012 Forest Code - we conducted a preliminary literature review to synthesize the body of laws pertaining to the socioenvironmental function of property, including their interpretations in legal doctrines and judicial decisions. Drawing on this synthesis, we examine how the stakeholders in land disputes in the south of the State of Bahia reached a peaceful solution to the problem. Based on our investigation of this process and the environmental principle underlying the social function of property, we seek to systematize a model that can serve as an example for similar situations in Brazil. The study was conducted in two stages. First, we performed a search and analysis of the main legal journals, doctrines, jurisprudence, and documents relevant to the theme. The second stage comprised a case study of peacefully resolved land disputes between landless movements and the forestry company Veracel Celulose S.A. in the Municipality of Eunápolis in the south of Bahia. This study included a qualitative analysis of relevant documents and the contracts signed between the company and the associations representing the family farmers involved in the disputes. Below we present a brief background and the current legal framework of the social function of property in Brazil. We then go on to describe this milestone in the pacific resolution of land disputes in this country and, based on our analysis, present this experience as a model that can serve as a new proposal for similar disputes.

\section{THE SOCIOENVIRONMENTAL FUNCTION OF PROPERTY IN BRAZIL - A LEGAL FRAMEWORK}


Agrarian reform is a theme that generates a series of social, economic, labor, environmental, and other tensions, which can be traced back to old judicial "rivalries" between public and private and natural law and positive law. Aristotle warned that man seeks to "accumulate possessions without end and without measure", claiming that human beings are by nature political and social animals, and that material goods are simply a means towards obtaining happiness and not an end in themselves ${ }^{1}$. In 1681, John Locke asserted that property should serve the purposes of the owners, before attending social interests. In other words, property is a natural right and its purpose transcends the will of the owner, thus establishing a general rule for land use ${ }^{2}$.

Articles 544 and 545 of the Napoleonic Code of 1804 established the absolute and exclusive right to enjoy and dispose of property, provided this usage did not violate any laws or regulations. Similarly, Article 17 of the Declaration of the Rights of Man and of the Citizen of 1789 established that property was an inviolable and sacred right, limited only by legally noted public necessity. This ideal therefore empowered the property owner with "the right not to use it, not enjoy it, not dispose of it, and consequently leave his land without cultivation, his urban sites without construction, his house without tenancy and without maintenance, his moveable capital unproductive"3.

In 1920, León Duguit presented the notion of property as a subjective right that obeyed a metaphysical and positivist logic. Moving away from the vision of property as an unlimited natural right, he introduced the concept of social function, whereby the function of a property should not be speculative, but rather satisfy "general needs"4. Thus, the right to property, initially grounded in a liberal

\footnotetext{
${ }^{1}$ ARISTÓTELES, 2006.

2 LOCKE, 2001. "Section 27. Though the earth, and all inferior creatures, be common to all men, yet every man has a property in his own person: this no body has any right to but himself. The labour of his body, and the work of his hands, we may say, are properly his. Whatsoever then he removes out of the state that nature hath provided, and left it in, he hath mixed his labour with, and joined to it something that is his own, and thereby makes it his property. Whatsoever then he removes out of the state that nature hath provided, and left it in, he hath mixed his labour with, and joined to it something that is his own, and thereby makes it his property. It being by him removed from the common state nature hath placed it in, it hath by this labour something annexed to it, that excludes the common right of other men: for this labour being the unquestionable property of the labourer, no man but he can have a right to what that is once joined to, at least where there is enough, and as good, left in common for others."

${ }^{3}$ DUGUIT, 1920, p. 173.

${ }^{4}$ PASQUALE, 2014, p. 103-105.
} 
and individualistic foundation, gave way to the notion of common good. This ideal was first adopted first by the 1917 Constitution of Mexico (Article 27) ${ }^{5}$ and later in the Constitution of the German Reich of 1919 (Article 153, Section 2) ${ }^{6}$. In Brazil, the concept was incorporated into the Constitution of Brazil of 1934 (Article 114, Section $17^{7}$ ) and reaffirmed in the constitutions of 1937 (Article 122, Section 14), 1946 (Article 147), and 1967 (Article 150, Section 22).

In this sense, the basis for the discussion of access to property as a way of promoting social justice lies in the public versus private goods dichotomy ${ }^{8}$ nested within the debate surrounding what constitutes the common and individual use of goods ${ }^{9}$. Equal opportunity to work the land and enjoy its fruits will only be ensured when access to land is guaranteed to all and fundamental rights are protected, including the right to an ecologically balanced environment enshrined in Article 225 of the CFRB ${ }^{10}$. Hence, "the social function of property is key to the stability of the economic order, since its absence leads to the abuse and impairment of the judicial legitimacy of property"11.

Land issues in Brazil have social, economic, political, and legal dimensions. For the purposes of this study, we focus on normative instruments and decisions relevant to these dimensions, placing special emphasis on the socioenvironmental function of rural property and how judges in Brazil have interpreted the application of this principal. In this regard, it is important to highlight that, in Brazil, the social function of property is addressed by both constitutional and infraconstitutional civil, administrative, and environmental legislation.

\footnotetext{
5 "The Nation shall have at all times the right to impose on private property such limitations as the public interest may demand as well as the right to regulate the development of natural resources, which are susceptible to appropriation, in order to conserve them and equitably distribute public wealth. For this purpose, necessary measures shall be taken to divide large landed estates; to develop small landed holdings; to establish new centers of population with such lands and waters as may be indispensable to them; to encourage agriculture and to prevent the destruction of natural resources, and to protect property from damage that is detrimental to society. [...]" (original text, 1917).

6 "Property imposes obligations. Its use shall constitute, at the same time, a service for the highest common interest".

7 "The right to property is guaranteed, which shall not be exercised against the social or collective interest [...]"

${ }^{8}$ SUNDFELD, 2010, p. 138-142.

9 LEROY, 2016.

${ }^{10}$ SILVA, 2017, p. 172; RABBANI, 2017, p. 211-215.

${ }^{11}$ FRANÇA, 1999. p. 20.
} 
From the outset, it is important to highlight that property transcends the absolute power of the owner to do what he wants with his property, occupying the status of relative power. In this respect, there has been a shift away from the unrestricted right to property towards a right limited by the fulfillment of the property's social function $^{12}$, as enshrined in the Brazilian Constitution (CFRB/1988).

The history of human rights ${ }^{13}$ shows that the fulcrum of legal norms is the control of social relations, representing either the necessary absence or necessary presence of the state to resolve conflicts. In the middle of the eighteenth century, the absolute power of the monarchy was limited in certain aspects of civil life, which corresponds to the rights established in Article 5 of the CFRB, notably freedom, security, and property.

Thus, property is enshrined within Brazil's constitutional framework as a fundamental right: "All persons are equal before the law, with no distinction whatsoever, and Brazilians and foreigners residing in the country are guaranteed the inviolable right to life, liberty, equality, security, and property [...]" (Article 5 of the CFRB). Section XXII of the same Article states that the right to property is guaranteed, while section XXIII, determines that "property shall perform its social function". Section XXIV further states that "the law shall establish procedures for expropriation for public necessity or utility, or for social interest, upon fair and prior financial compensation, with the exception of cases set forth in this Constitution [...]". Finally, section XXVI provides that small rural properties whose owners practice family farming shall not be liable to attachment for payment of debts stemming from productive activities and that the law shall establish provisions on ways to finance the development of the property.

Further on, Article 170 sets out general principles relating to economic activity, providing that the economic order is founded on the appreciation of the value of human labor and free enterprise and should ensure that everyone can enjoy a life with dignity, making specific reference to the principle of the social function of property in section III. In this Article, it is evident that social function serves to limit the economic order:

12 COLINA GAREA, 1995.
13 WOLKMER, 2002, p. 9. 
"[...] it is vital that Brazilian society recognizes the social function of property as a principle that is essential to the very existence of property and the economic order; in other words, to the realization of social well-being demanded by the Federal Constitution to preserve its stability. The social function of property is not the sacrifice of private property, but rather the solid guarantee of its peaceful maintenance." 14

Article 182 focuses on the regulation of urban development policy. Paragraph 2 provides that "Urban property performs its social function when it conforms to the fundamental requirements for city planning expressed in the master plan", while paragraph 4 empowers local governments to require in the master plan that owners make adequate use of non-built, under-used, or unused urban land. Hence, it is clear that the principle of the socioenvironmental function of property applies both to urban and rural property.

With specific reference to rural property and agrarian reform, Article 186 states that:

"The social function is performed when rural property simultaneously complies with the following requirements, in accordance with the criteria and standards prescribed by law: I. rational and adequate use; II. adequate use of available natural resources and preservation of the environment; III. observance of the provisions regulating labor relations; IV. exploitation that favors the well-being of owners and workers."

With regard to the socioenvironmental dimension of rural property, the above provisions show that land use should be rational and adequate and ensure the adequate use of available natural resources and the preservation of the environment. There is therefore an umbilical relationship between the environment, natural resources and the social function of property: the socioenvironmental element of property is intrinsic to land use.

In Brazil's Civil Code (Law 10.406, January, 10 ${ }^{\text {th }}, 2002$ ), social function is considered to be a limitation on both contracts and property, with Article 421 providing that "The freedom of contract shall be exercised by virtue and within

\footnotetext{
14 FRANÇA, 1995, p. 13.
} 
the limitations of the social function of the contract". Furthermore, Article 1.228 states that:

"The owner has the right to use, enjoy and dispose of the thing, and the right to recover it from the power of anyone who wrongly possesses or holds it. $§ 1$ The right of property shall be exercised in accordance with its economic and social purposes and, in conformity with the provisions of special laws, to preserve flora, fauna, natural beauty, ecological equilibrium, and historical and artistic heritage, and to avoid air and water pollution.

$\S 2$ Acts that do not bring the owner commodity or utility and animated by the intention of harming others are not permitted.

$\S 3$ The owner may be deprived of the thing in cases of expropriation for public need or utility or for social interest, as well as in cases of requisition in the event of imminent public danger.

$\S 4$ The owner may also be deprived of the thing if the claimed property consists of an extensive area under uninterrupted good faith possession by a considerable number of persons for a period over five years, who have carried out within the said area, jointly or separately, works and services that the judge considers to be of relevant social and economic interest.

$\S 5$ In the case of the foregoing, the judge shall set fair compensation payable to the owner; paid the price, the sentence shall be valid as a title for the registration of the property in the name of the possessors."

In the same sense, the sole paragraph of Article 2.035 of the Civil Code stipulates "no provision shall prevail if it is contrary to the public order, established by this Code to ensure compliance with the social function of property and contracts". It is precisely this social dimension that is the focus of this work, which describes an example of how private owners can resolve judicial/social disputes by negotiating a consensual settlement with the other stakeholder.

Article 2 of the Land Statute (Law 4.504, November 30 ${ }^{\text {th }}$, 1964) states that everyone shall be assured the opportunity of access to land ownership, conditional upon its social function. This social function is fulfilled when, simultaneously, it: "a) promotes the well-being of the owners and the workers who work on the land and their families; b) maintains satisfactory levels of productivity; c) assures the conservation of natural resources; d) observes the legal provisions 
regulating fair employment relationships between those who own the land and those who cultivate it"15. In the same vein, Law 4.132 (September 10 ${ }^{\text {th }}, 1962$ ) provides for the expropriation of land in the social interest for the purpose of "promoting the fair distribution of property or conditioning its use to social wellbeing [...]" (Article 1). Article 2 characterizes social interest as follows:

"I - the use of all unproductive or exploited property that does not correspond to the housing, employment and consumption needs of population centers that it should or can supply considering its intended economic use;

II - the planting or intensification of crops in areas whose use does not obey the agricultural zoning plan, VETOED;

III - the establishment and maintenance of agricultural settlements and work colonies and cooperatives;

IV - the maintenance of squatters on urban lands where, with the owner's express or tacit tolerance, they have built their houses, forming residential areas of more than 10 (ten) families;

$\mathrm{V}$ - the construction of popular houses;

$\mathrm{VI}$ - land and waters susceptible to extraordinary increase in value due to the completion of public works and services, notably sanitation works, ports, transport, electrification, water storage and irrigation, in cases where the said areas are not being used for the social good;

15 Law 4.504/1964 continues: [...]

Art. $2[\ldots] \S 2$ It is the duty of the government to:

a) promote and create the conditions for rural workers to access the ownership of economically useful land, preferably in the regions they inhabit or, depending on regional circumstances, advise workers in zones previously adjusted in accordance with the provisions of the regulation of this Law;

b) ensure that land ownership performs its social function, stimulating plans for its rational use, promoting fair remuneration and access to the benefits of increased productivity and collective well-being for workers.

$\S 3$ All farmers have the right to remain on the land they cultivate within the terms and limitations of this Law and observing, where applicable, the rules governing employment contracts.

$\S 4$ Indigenous populations shall be assured the right to possession of the lands they occupy or that are attributed to them in accordance with special legislation governing the tutelary regime that they are subjected to.

[...]

Art. 12. Private land ownership has an intrinsic social function and its use shall be conditioned to collective well-being, as set out in the Federal Constitution and characterized in this Law. [...] Art. 13. The government shall promote the gradual extinction of forms of land occupation and exploitation that contradict their social function. 
VII - the protection of soil and preservation of watercourses and sources and forest reserves.

VIII - the utilization of areas, places or goods, which, due to their characteristics, are suitable for the development of tourist activities. (Section added by Law 6.513, December 20 $\left.{ }^{\text {th }}, 1977\right)$.

$\S 1$ The provision in item I of this article shall only apply to property removed from production or rural properties whose productivity, due to inefficient exploitation, is lower than the regional average, taking into account the natural soil conditions and market situation.

$\S 2$ Housing, employment and consumption needs shall be assessed annually by the authorities charged with ensuring the well-being and supply of the respective populations, according to the local economic conjuncture and conditions."

It is understood that Law 4.132/1962 was embodied in the CFRB precisely because of the normative framework that it created for expropriation in the public interest. It is important to emphasize section VII of Article 2, which provides for expropriation to protect the soil and preserve watercourses and sources and forest reserves. This Article is intrinsically linked to the National Environment Policy (Law 6.938, August 31 st 1981 ) and specific provisions of the new Forest Code (Law 12.651, May 15 ${ }^{\text {th }}, 2012$ ).

Law 8.629 (February $15^{\text {th }}$, 1993), subject to amendments introduced by Law 13.465 (July $11^{\text {th }}, 2017$ ), regulates the provisions of the Constitution concerning agrarian reform, establishing that the Union may expropriate rural property that does not fulfill its social function (Article 2), paying in advance fair compensation (Article 5). Article 9 establishes the following criteria for assessing whether or not a rural property is performing its social function: "I - rational and adequate use; II - adequate use of available natural resources and preservation of the environment; III - observance of the provisions regulating labor relations; IV exploitation that favors the well-being of owners and workers". These criteria are described in greater detail in Article $9^{16}$.

${ }^{16}$ BRASIL, 2019. 
Thus, under the current legal framework in Brazil, the social function of property has three dimensions: economic, social, and environmental. From the environmental point of view, the term "socioenvironmental function of property" embraces all the principles and regulations that make up environmental law. The CFRB provides the basis for environmental protection in Article 225 ${ }^{17}$, linking it directly to "human dignity" (Article 1, III), quality of life, and health (Article 5), since quality of life depends on the quality of the environment. On the other hand, while property is a means of creating socioeconomic value, the socioeconomic and environmental function of property can only be fulfilled when the state and society understand that its use should respect the values of the Rule of Law and democracy, ensuring that the benefits arising from rational land use are shared among all actors.

Brazil's new Forest Code (Law 12.651, May 25 ${ }^{\text {th }}, 2012$ ) adds two fundamental obligations for private rural lands, which are: "Permanent Preservation Areas" (Áreas de Preservação Permanente) ${ }^{18}$ and "Legal Reserves" (Reservas Legais) ${ }^{19}$. These obligations were introduced by the previous Forest Code (1965), which established new parameters for native vegetation protection in rural areas, acknowledging the relationship between the spatial structure of native vegetation and biodiversity conservation, as well as preventing erosion and ensuring environmental conditions for public welfare ${ }^{20}$. The "Rural Credit" (Crédito Rural) was also created in 1965 to reduce costs and offer funding to promote exportation of agricultural products, such as coffee, sugar, cotton, and cocoa. The objective

\footnotetext{
${ }^{17}$ CRFB, Article 225: "Everyone has the right to an ecologically balanced environment, which is a public good for the people's use and essential for a healthy life. The Government and the community have a duty to defend and to preserve the environment for present and future generations".

18 "Permanent Preservation Areas" (Áreas de Preservação Permanente) are considered a "protected area, covered or not by native vegetation, with the environmental function of preserving water resources, the landscape, geological stability, and biodiversity, facilitating the gene flow of fauna and flora, protecting the soil, and ensuring the well-being of human populations" (Article $3^{\circ}$, II).

19 "Legal reserve" is defined in Brazilian legislation as an area located inside a rural property (ownership or possession) which aims to ensure the sustainable economic use of natural resources, assisting the conservation and rehabilitation of ecological processes, promoting the conservation of biodiversity, and sheltering and protecting wild fauna and native flora (Article 3o, III, Law 12.651/2012).

Therefore "legal reserve" is an area that must be maintained with native vegetation coverage within the rural property, in ownership or possession, and that has a significant environmental importance, because it can provide a sustainable economic use of the natural resources.

20 IGARI; PIVELLO, 2011.
} 
was to transform national agriculture, financing the infrastructure and mechanization required to make agriculture more productive, through marketing, storage, and industrialization ${ }^{21}$.

It is interesting to mention that the Forest Code and Rural Credit Law were conceived in the same year (1965), just one year after the Land Statute, and fostered opposing perspectives regarding land use change. On one hand, the Land Statute and Rural Credit Law sought to better distribute the land, in order to achieve social justice and an increase in productivity, without neglecting the importance of environmental protection. On the other hand, the Forest Code of 1965 promoted great progress in environmental protection in Brazil. Furthermore, the Forest Code reform of 2012 addressed some historical conflicts with the Rural Credit Law. The current Forest Code regressed somewhat with regard to environmental protection, as outlook of the political actors who proposed and approved the previous Forest Code (Law 4.771, September 15 th, 1965 ) differed greatly from that which guides the current "ruralists" 22 , as they understood at that time that environmental conservation was a positive vector for agricultural productivity, not as an economic growth ${ }^{23}$.

In this case study, the environmental effects of these negotiations on the South of Bahia (Brazil) are achieved by defining zones in which each family will work the land, preserving legally protected environmental areas from unorganized occupation of the land. Forestry is the sector which shows the highest level of compliance to the Forest Code, compared to agriculture and cattle ranching. The size of the property, social groups, and economic activities are also important in the formulation of public policies for environmental conservation in rural areas ${ }^{24}$. In this sense, Brazil's new Forest Code defines social interest in Article 3, Section IX, Paragraphs b) and d):

“[...] b) sustainable agroforestry practiced on small properties or family small holdings or by indigenous peoples and traditional communities, when it does

\footnotetext{
${ }^{21}$ IGARI; PIVELLO, 2011.

22 "Ruralists" (ruralistas), in Brazil, refers to the large landholders and their representatives.

${ }^{23}$ IGARI; PIVELLO, 2011.

${ }^{24}$ LEITE et al., 2020. The same authors emphasize that land reform settlements did not show a different level of Forest Code compliance compared to other land tenure categories.
} 
not mischaracterize the existing vegetation cover or compromise the environmental function of the area; [...]

d) land tenure regularization in human settlements occupied predominantly by low-income populations in consolidated urban areas, observing the conditions set out in Law 11.977 of July 2009 [...]"

The Forest Code permits, in exceptional circumstances, intervention or removal of native vegetation in permanent preservation areas located in areas undergoing land tenure regularization occupied by low-income populations to carry out housing and urbanization works (Article $8, \S 2)^{25}$. In contrast, the Code amends Article 35 of Law 11.428 (December $22^{\text {nd }}, 2006$ ), providing that:

"On both rural and urban property, the conservation of primary and secondary vegetation in the Atlantic Forest Biome, regardless of the successional stage, performs a social function and is of public interest, and, at the owner's discretion, the areas subject to the restrictions set out in this Law may be calculated as Legal Reserve and any excess used for environmental compensation or as an Environmental Reserve Quota - ERQ. (Text from Law 12.651 of 2012).

Sole paragraph. Except as otherwise provided by law, permanent preservation areas are not part of the legal reserve."

The Supreme Court (Supremo Tribunal Federal or STF in Portuguese) applied these provisions in passing an order for injunction in the Direct Action of Unconstitutionality $\mathrm{n} \times 2.231$. Considering that a "critical social mortgage weighs" on the right to property, the Court understood that this right is not absolute if the social function inherent to property set out in Article 5, section XXIII of the CFRB is not fulfilled. Thus, according to the STF, the state has the right to intervene in the private sphere, provided that the limitations set out in the Constitution are safeguarded, whereby expropriation is a "constitutional sanction imposable for non-compliance with the social function of property" and therefore an important instrument for the fulfillment of the state's commitments in the economic and

\footnotetext{
${ }^{25}$ It is important to mention that the Forest Code created the Rural Environmental Registry (RER), a mandatory electronic registry of the status of permanent preservation areas, legal reserves, forest areas, remnants of native vegetation, restricted use areas, and consolidated areas of rural properties. The RER therefore provides key information for controlling, monitoring, and combating deforestation and constitutes an important tool for the environmental and economic planning of rural properties.
} 
social spheres. In the same decision, the STF also ruled that the owner has a legal and social duty to cultivate the land and ensure its adequate use, otherwise it is likely to fall within the sanction provisions pertaining to idle, uncultivated, and unproductive land 26 .

The STF also determined that the state has the right to expropriate rural properties for agrarian reform purposes, having the duty to ensure that the integrity of the land's environmental assets is respected. It also emphasizes that, to fulfill the social function of the property, the owner has an obligation to ensure the adequate use of available natural resources and preservation of the environment, in accordance with Article 186, II of the CFRB and under penalty of expropriation for failure to do so, as set out in Article 184. The right to an ecologically balanced environment is therefore a third generation or "solidarity right"; that is, society has non-disposable and inexhaustible prerogative ownership of the environment ${ }^{27}$. Thus, the expropriation of rural property in the social interest is "a reaction of the state to the deviation of the social function inherent in private property" with fair compensation paid in advance in government bonds, guaranteeing the right to private property ${ }^{28}$.

On the other hand, the Regional Federal Court of the 2nd Region (Tribunal Regional Federal da $2^{a}$ Região or TRF-2) decided that expropriation for the purposes of agrarian reform shall respect the limitations of productivity and the socioenvironmental function of property, stating that productive property is not susceptible to expropriation and that expropriation for the purposes of agrarian reform should be grounded in "environmentally degrading activity"29.

In response to a claim brought by the National Institute for Colonization and Agrarian Reform (INCRA), the Regional Federal Court of the 1st Region (TRF-1) granted recovery of possession against squatters occupying a "legal reserve" in the agrarian reform settlement Santa Anna in Araguapaz in the State of Goiás, defending that "occupation of an area for a long time is no justification for

\footnotetext{
${ }^{26}$ STF, 2004; STF, 2010.

27 STF, 1995.

${ }^{28}$ STF, 1993.

29 TRF-2, 2013.
} 
maintaining possession, since the owner has a duty to restore the degraded area if it is destined for legal reserve"30.

In this sense, the cases involving land disputes in south of Bahia in which Veracel Celulose S.A. brought actions for the recovery of possession are examples of the reorganization of property by the stakeholder without effecting an expropriation sanction for the non-fulfillment of social function. In such cases, the role of the state is reduced to a minimum, as are government costs, since, instead of compensation, the land is bought by the family farmers under an arrangement similar to that of the "National Land Credit Program"31 in Brazil. It is interesting to note that the main driving force that led to these agreements was the need to reach a settlement. Instead of pursing a costly and protracted litigation process, the stakeholders decided to "adapt" to the situation and satisfy their mutual demands by reaching a dispute settlement.

Therefore, the settlements reached by Veracel Celulose S.A. and the landless movements proved to be a cost-effective way of achieving the objectives of the norms and decisions of Brazil's courts. However, despite the success of the settlements and the fact that the normative base of the agreements is effectively grounded in the notion of the social function of property, the actions and agreements studied made absolutely no mention of the principle, as will be demonstrated below.

With regard to the social function of the legal agreements between the landless movements and Veracel, it is important to consider Executive Order 881 issued on April 30 $0^{\text {th }}, 2019$, and converted into Law 13.874 (September 20 ${ }^{\text {th }}, 2019$ ), known as the "Economic Freedom Act". This instrument embodied a retrograde position in relation to contractual limitations by amending Article 421 of the Civil Code. The amendment substituted the original version ("the freedom to contract will be exercised by reason and within the limits of the social function of the

\footnotetext{
30 TRF-1, 2011.

${ }^{31}$ The "National Land Credit Program" (PRONAF - Programa Nacional de Fortalecimento da Agricultura Familiar) is a financing program for funding investment in the implantation, expansion, or modernization of production, processing, industrialization, and services infrastructure in rural establishments or in nearby rural community areas, aiming to generate income and improve the use of family labor. This program is supported by the Brazilian federal company known as the "National Economic and Social Development Bank" (BNDES - Banco Nacional de Desenvolvimento Econômico e Social).
} 
contract") for the following text: "the freedom to contract will be exercised by reason and within the limits of the social function of the contract, observing the provision set out in the Declaration of Rights to Economic Freedom". It goes on to add a sole paragraph stating that: "in private contractual relations, the principle of minimum state intervention, by any of its powers, shall prevail and contractual review by external parties shall be undertaken only under exceptional circumstances".

Law 13.874/2019 reiterated this position, albeit clothed differently: "Article 421. The freedom to contract will be exercised within the limits of the social function of the contract". It goes on to state in the sole paragraph that "in private contractual relations, the principle of minimum state intervention and the exceptionality of contract review shall prevail”, incorporating a new Article 421-A:

\footnotetext{
"Civil and business contracts are assumed to be equal and symmetrical, unless there are concrete elements that justify the withdrawal of this assumption, except for legal regimes set out in special laws, also guaranteeing that: I - the parties may establish objective parameters for the interpretation of the negotiated clauses and of the assumptions for review or resolution; II - the risk allocation defined by the parties shall be respected and observed; and III contractual review shall only take place under exceptional and limited circumstances."
}

There is therefore a clear trend toward limiting the role of the state, using the reduction of bureaucracy, and simplifying private relations as an excuse to reduce the burden on the state. There is also the question of constitutionality. In this regard, executive orders should only be issued in cases that are viewed as relevant and urgent (Article 62 of the CFRB). The new Economic Freedom Act law is inconsistent with the ideals underlying the structure of legal systems in democratic states bound by the Rule of Law, taking us back to the historical debate about the conflict between public and private and the need for state regulation to avoid certain abuses. 


\section{LAND DISPUTES AND CONSENSUAL RESOLUTIONS IN THE SOUTH OF BAHIA: OBSERVATIONS AND REFLECTIONS}

In recent years, the south of Bahia has witnessed increasing numbers of land disputes between forestry companies and landless movements, indigenous peoples, and quilombolas. It could be said that the first attempts to reach an agreement began in 2011, with the Landless Rural Workers Movement (MST Movimento dos Trabalhadores Rurais sem Terra) being the first movement to enter into dialogue with Veracel Celulose S.A. It is important to stress, however, that an array of landless movements in the region that have come to the negotiating table in recent years, including: a Federação dos Trabalhadores na Agricultura (Federation of Agricultural Workers - FETAG), Movimento de Luta pela Terra (Struggle for Land Movement - MLT), Frente dos Trabalhadores Livres (Free Workers Movement - FTL), Federação dos Trabalhadores e Trabalhadoras na Agricultura Familiar (Federation of Family Farmer Workers - FETRAF), and Central Estadual de Associações das Comunidades Tradicionais da Agricultura Familiar e Campesina da Bahia (Center for Associations of Traditional Family and Peasant Farmer Communities in Bahia - CECAF/BA). The common thread between these organizations is the occupation of forestry company lands, with the high concentration of land ownership in the hands these companies being a major driving factor of disputes in the region. Indeed, "in Brazil, occupation is the main strategy adopted by landless movements in the struggle for land"32.

Veracel Celulose S.A. owns 200,814 hectares of land distributed across 11 municipalities in the south of Bahia, including 91,882 hectares of planted area and 98,100 hectares of permanent preservation areas and legal reserves. In addition, the company has 22,452 hectares planted under its Forest Producer Program ${ }^{33}$.

In the last decade, the landless movements have strengthened their capacity and occupied 30 areas owned by forestry companies in the region. As a result of their persistence, strategy, pressure, and political articulation, these movements have

${ }^{32}$ GIRARDI, 2008, p. 274.
33 VERACEL, 2019, p. 13. 
achieved several victories. At the same time, forestry companies, interested in increasing access to global markets through certification and programs like those offered by the Forest Stewardship Council, the world's leading forest certification scheme, have changed the way they operate in relation to landless movements in an attempt to quell historical socioenvironmental conflicts.

The first agreement, involving Veracel Celulose S.A., the Government of the State of Bahia, INCRA, and six movements representing approximately 1,200 family farmers, was reached in 2013. Under the agreement, the company transferred around 20,000 hectares of land to INCRA for the creation of rural reform settlements and undertook to provide technical assistance and agricultural extension services to the family farmers, resulting in the Projeto Assentamentos Agroecológicos Sustentáveis (Sustainable Agroecological Settlements Project), implemented by the University of São Paulo's Luiz de Queiroz College of Agriculture (ESALQ). However, the project faced a series of challenges, mainly due to the country's growing political instability, weakening INCRA's actions in the region and delaying the land tenure regularization process and creation of the settlements. Furthermore, this agreement covered only part of the disputed areas. Thus, in 2018, the company proposed a new initiative.

The case study involves a multidimensional dispute (social, economic, and environmental) between eucalyptus plantations - represented by Veracel Celulose S.A. - and family farming - represented by the landless movements which occupied company lands. The land disputes addressed here are centered on actions brought by Veracel Celulose S.A. for the recovery of possession and were resolved through negotiations between the stakeholders mediated by the Bahia State Department of Justice, Human Rights and Social Development. These negotiations resulted in the purchase and sale agreements, in which the sale of the occupied land by Veracel Celulose S.A. to the family farmers was settled, in exchange for payments over a twenty-year period, under which the farmers are entitled to access the lands.

Between 2009 and 2016, Veracel Celulose S.A. filed various lawsuits in the Bahia State Court of Justice for the recovery of possession of the properties "Fazenda Mutum" and "Fazenda Sítio Esperança" (numbers 0004935-16.2009.8.05.0079, 
0000023-05.0211.8.05.0079,

0003118-43.2011.8.05.0079,

000311758.2011.8.05.0079, and 0501676-09.2016.8.05.0079). The lawsuits were brought against the following family farmer associations: Associação Agropecuária Domingos Ascoagro, Associação Nova Vitória, Associação 2 de Julho, Associação Sapucaeirinha ${ }^{34}$, and Associação Miramar.

As the legal owner of these properties, Veracel Celulose S.A. signed court orders dated November $21^{\text {st }}$ and $22^{\text {nd }}, 2018$, under which it undertook to enter into partial and individual purchase and sale agreements and promised to donate part of the disputes areas, thus transforming the hitherto unlawful occupation into secure possession of the land.

As part of the company's environmental commitments, the Pau Brasil Agroecology and Organic Production Study Group (NEA-PB) at the Federal University of the South of Bahia (UFSB) provides support and collaborates with the farmers under the research and extension project Socioenvironmental Development for Family Farming (DSAF). The aim of the project is to promote the adoption of sustainable farming practices, restoration of degraded areas, conservation of biodiversity, and socioenvironmental development, specifically focusing on the certification of agricultural products, inclusion of family farmers in value chains, and income generation. The project encompasses four areas totaling 2,951.78 hectares as shown in Table 1.

Table 1: Areas occupied in farms belonging to Veracel Celulose S.A. in Eunápolis assisted by the Socioenvironmental Development for Family Farming project implemented by the NEA-PB, 2020.

\begin{tabular}{lccc}
\hline Farms & Associations & Number of families & $\begin{array}{c}\text { Area occupied } \\
\text { (hectares) }\end{array}$ \\
\hline Fazenda Mutum & Nova Vitória & 64 & 306.65 \\
Sítio Esperança & Sapucaerinha & 62 & 161.98
\end{tabular}

\footnotetext{
${ }^{34}$ Associação Agropecuária Domingos Ascoagro and Associação Nova Vitória later merged, creating one single association called Associação Nova Vitória.
} 


\begin{tabular}{llcc}
\hline & 2 de Julho & 103 & $1,262.51$ \\
\hline Fazenda Miramar & Miramar & 82 & $1,220.64$ \\
\hline Total & $\mathbf{4}$ & $\mathbf{3 1 1}$ & $\mathbf{2 , 9 5 1 . 7 8}$ \\
\hline
\end{tabular}

The NEA-PB also conducted studies related to the recognition of these areas, verifying existing crops, livestock, access and trafficability, housing conditions, access to water, and the status of the legal reserves and permanent preservation areas. These assessments were undertaken in conjunction with members of the associations, legitimizing NEA-PB's work in these communities. The NEA-PB, in conjunction with a company outsourced by Veracel Celulose S.A. and members of the family farmer associations, also conducted the subdivision of the four areas into family lots.

This process involved a series of meetings with the associations to define the distribution of the land taking into consideration the specific characteristics of the areas (soil conditions, permanent preservation areas and legal reserves, farmers' capacity for developing specific activities, and an assessment of ability to pay for the land). An essential element of this process is the fulfillment of the socioenvironmental function of property in accordance with constitutional and infraconstitutional legislation. The mediated discussions between the stakeholders enabled the elaboration of a map showing the subdivision of the areas and, based on this map, the definition of specific strategies to achieve social, economic, and environmental goals.

The study of the social function of property and land issues in Brazil shows that there is a certain tension between legal values and principles, such as private property rights, economic freedom, free enterprise, and freedom of competition on the one hand, and the right to work, a dignified life, balanced environment, health, housing etc. on the other. If we consider that the function of law is to keep the peace and promote social harmony, these apparently conflicting principles should converge to generate a claim that best serves the interests of both parties. This raises questions about legal tradition in the Brazilian state and how this is 
reflected in society. In this regard, the present study cannot ignore critical theories of law in its search for a new proposal for the application of the law in accordance with historical and social elements that seek social harmony.

Human beings are by nature political animals and "he who is without a city through nature rather than chance is either a mean sort or superior to man, [...] for the one who is such by nature has by this fact a desire for war, as if he were an isolated piece in a game of chess"35. Indeed, for Aristotle, to be a "man" (citizen), one must have possessions. These Aristotelian premises demonstrate the need to rethink Eurocentric philosophical proposal that remain entrenched in legal perceptions ${ }^{36}$. The purpose of law should be to satisfy the "common good" and the materialization of power through the creation and application of laws sometimes protects the interests of specific social groups ${ }^{37}$.

Society is organizing itself to conquer "new" rights ${ }^{38}$, not in pursuit of income or absolute equality, but rather equality of opportunity ${ }^{39}$. Demystifying the categorically theoretical notions of legal pluralism, alternative law, "law found on the street", and "judges for democracy", this case study realizes the theorized aspirations underlying these progressive doctrines within the factual realm. The occupation of lands by these landless movements, judicialization of actions for recovery of possession, and negotiation of peaceful solutions illustrates not only the lack of effectiveness of the legal system, but also the importance of problematizing normative/positive law ${ }^{40}$.

The reshaping of the company's social role in face of the social function of property has enabled family farmers to exercise their right to work, livelihood, and a dignified life through the purchase of lands that would otherwise be the target of long drawn-out legal battles, almost certainly leading to an exhausting and costly conflict for both sides. In this sense, the alternative found by the litigants

\footnotetext{
${ }^{35}$ ARISTRÓTELES, 2006.

${ }^{36}$ WOLKMER, 2015.

${ }^{37}$ AGUIAR, 1990.

38 WOLKMER, 2003.

${ }^{39}$ MARSHALL, 1967.

${ }^{40}$ As proposed by authors like Roberto Lyra Filho (2017), Antônio Carlos Wolkmer (2002; 2003; 2015), Noberto Bobbio (2004), José Geraldo de Sousa Júnior (2011), Boaventura de Sousa Santos (2015), and Amilton Bueno de Carvalho (1998).
} 
optimizes the application of the normative values embodied in the principles of Brazilian law.

In 1897, Vilfredo Pareto highlighted the mutual dependence between the economy and social phenomena, suggesting that it was possible to optimize the distribution of resources between the agents involved in a system or a market. He observed that $80 \%$ of the total wealth of a nation was held by only $20 \%$ of the population, a concept known today as the Pareto principle or 80-20 rule. He also proposed what economists call "Pareto optimality", which is a situation where, for some individual to gain, one or more other individual must necessarily lose. That is, a situation where an economic agent cannot increase his or her appropriation of a given good or service without losses of those goods of services incurred by other agents ${ }^{41}$.

The Pareto optimality can be used as a limit in this case study in order to avoid a result where "someone would have to lose in order for another to win". It is evident that Veracel Celulose S.A. avoided a financially, politically, and socially costly process that would have involved long and grueling legal battles and almost certainly violent evictions. On the other hand, the family farmers avoided being victims of the coercive force of the state and the constant concern that their homes and crops could be destroyed at any time. The sale of the land below market value with payments over an extended period of time was a satisfactory outcome for both stakeholders, each of whom partially gave way to the interests of the other to achieve a common goal: by reducing their own well-being, they could achieve a global security and comfort with positive impacts for the environment, for the economy, and for the people involved.

\section{FINAL CONSIDERATIONS}

Under Brazilian law, the social function of rural property has three concomitant dimensions: economic, which emphasizes productivity and the rational and adequate use of the property (Law 8.629, February 25 ${ }^{\text {th }}, 1993$ ); social, tied to the principle that all people should be able to lead a dignified life (Article 1, III, and Article 170 of the CFRB) and incorporating the protection of

\footnotetext{
${ }^{41}$ PARETO, 1996, p. 6.
} 
employment relationships and idea that land use should promote the well-being of both owners and workers; and environmental, which refers to the adequate use of natural resources and environmental preservation (Articles 186 and 225 of the CFRB).

This study demonstrates successful experiences that led to the peaceful resolution of long-standing land disputes between Veracel Celulose S.A. and organized groups of family farmers in the south of Bahia. Under the settlements, the company sold part of its land at an affordable price in payments over a twentyyear period, thus redistributing the land without the need to impose an expropriation sanction.

The environment also is benefitted by the mediated negotiations between the stakeholders involved: by designating the exact zones in which family farming will occur, these negotiations provide for the preservation of legally protected environmental areas that would otherwise be destroyed by the invasion of farming.

The farm areas negotiated in the context of this agreement were unproductive and would be destined to the cultivation of large tracts of Eucalyptus, representing in both situations a simplified rural landscape characterized by social vacuum and low ecosystem diversity.

From the regularization of the occupation by family farmers together with qualified technical assistance, it can be considered that a process of landscape enrichment has begun, with a significant increase in the diversity of agricultural production, forming agro-ecosystems that are also promoters of ecosystem services. An example would be the implementation of agroforestry systems which, in addition to producing food for direct consumption, also produce fibers and oils, and help to form strategic ecological corridors for the promotion of ecosystem services, such as soil, water, and biodiversity conservation. These results are monitored by the NEA-PB team using indicators established by the United Nations (UN) in the context of the seventeen Sustainable Development Goals (SDGs).

This solution therefore resulted in social benefits in the form of reduced social costs: the state did not need to expropriate the land; the company did not incur the cost of a drawn-out legal dispute; and the family farmers were guaranteed the 
opportunity to purchase and cultivate the land. Thus, the socioenvironmental purpose of the land was duly fulfilled, although no mention was made of the social function of property throughout the process.

It is important to highlight, however, the link between the company's dispute resolution strategy and corporate social and environmental responsibility, considering national and international forest certification schemes such as the FSC, Brazilian Forest Certification Program (CERFLOR), and Programme for the Endorsement of Forest Certification (PEFC). The case study illustrates how consumer demand for green products can drive companies to adopt sustainable and socially responsible practices. In this regard, the solution represents a gain for the company insofar as it increases access to this type of national and global market.

The social function of property and land disputes in Brazil face age-old challenges rooted in society and the state. Much more discrimination, suffering, and denial of rights is likely to be inflicted on our people before a new social order emerges, grounded in common good and social pacification. Critical theories of law can help understand the failings of the system and search for new proposal that give a louder voice to the struggle for better days in which rights and equal opportunity are safeguarded, where no one will have to lose so that someone else can win: every stakeholder will have to reduce their own well-being in order to achieve a "common good".

This study intends to provide a glimmer of hope for social relations between the "dominant" and the "dominated", in which it is possible to benefit entire communities and promote family farming without adversely affecting the financial performance of large companies such as Veracel Celulose S.A. Corporate social responsibility includes respecting local communities and their right to a dignified life and this study demonstrates that such commitments can be undertaken in the name of the social function of property and adhering to the values the Rule of Law and democracy.

\section{REFERENCES}


AGUIAR, Roberto A. R. Direito, poder e opressão. 3. ed. São Paulo: Alfa-Omega, 1990.

ARAUJO, Luiz Ernani Bonesso. A questão fundiária na ordem social. Dissertação de mestrado do curso de pós-graduação em Direito. UFSC: Santa Catarina, 1984, p. 60.

ARISTÓTELES. A política. Coleção grandes obras do pensamento universal. 1. ed. São Paulo: Lafonte, 2017.

BOBBIO, Norberto. A era dos direitos. Trad. de Carlos Nelson Coutinho. Rio de Janeiro: Elsevier, 2004.

BRASIL, Luciangela Ferreira do. As alterações da política agrária: um debate hermenêutico acerca da reforma agrária. Dissertação Programa de PósGraduação em Direito Agrário. Universidade Federal de Goiás: Goiânia, 2019.

BÜHRING, Marcia Andrea. A efetiva função da propriedade: a socioambiental. Função socioambiental da propriedade. Caxias do Sul: EDUCS, 2016, p. 11-38.

CARVALHO, Amilton Bueno de. Teoria e prática do direito alternativo. Porto Alegre: Síntese, p. 58, 1998.

COLINA GAREA, Rafael. La función social de la propiedad privada en la Constitución española de 1978. 1995.

DUGUIT, León. Las transformaciones generales del derecho privado desde el Código de Napoleón. 2. ed. Madrid: Francisco Beltrán, Librería española y extranjera, 1920.

FRANÇA, Vladimir da Rocha. Função social da propriedade na Constituição Federal. Revista Jurídica In Verbis. Natal: UFRN/ CCSA/Curso de Direito, maio/jun. de 1995. p. 7-13.

FRANÇA, Vladimir da Rocha. Perfil constitucional da função social da propriedade. Revista de Informação Legislativa. Brasília: Senado, Brasília a. 36 n. 141 jan./mar. 1999, p. 9-21.

GIRARDI, E.P. Proposição teórico- metodológica de uma cartografia geográfica crítica e sua aplicação no desenvolvimento do atlas de questão agrária brasileira. 2008. 347 p. Tese (Doutorado em Geografia) - Faculdade de Ciências e Tecnologia, Universidade Estadual Paulista, Presidente Prudente, 2008.

LEITE, Melina de Souza; SILVA JUNIOR, Joaquim Alves da; CALABONI, Adriane; IGARI, Alexandre Toshiro. Fatores socioeconômicos e a vegetação nativa em imóveis rurais no Estado de São Paulo. Ambiente \& Sociedade, v. 23, 2020. 
LEROY, Jean Pierre. Mercado ou bens comuns: o papel dos povos indígenas, comunidades tradicionais e setores do campesinato diante da crise ambiental. Rio de Janeiro: Federação de Órgãos para a Assistência Social e Educacional (FASE), 2016.

LYRA FILHO, Roberto. O que é direito? Coleção primeiros passos n. 62. Brasília: Brasiliense. 2017.

LOCKE, John. Segundo Tratado sobre o Governo Civil: ensaio sobre a origem, os limites e os fins verdadeiros do governo civil [1681]. Trad. Magda Lopes e Marisa Lobo da Costa. 3. ed. Vozes: Petrópolis, 2001.

IGARI, Alexandre T.; PIVELLO, Vânia R. Crédito rural e código florestal: irmãos como Caim e Abel?. Ambiente \& Sociedade, 14(1), 133-150, 2020.

MARSHALL, Thomas. Humphrey. Cidadania, Classe Social e "Status". Rio de Janeiro: Zahar Editores, 1967.

NAREZI, Gabriela; ANDRADE, Fernando Rabello Paes de; VALENTE, Aline Aparecida. A produção do eucalipto e a questão agrária: uma proposta de desenvolvimento socioambiental para a agricultura familiar no sul da Bahia. Jornada de Estudos em Assentamentos Rurais. Faculdade de Engenharia Agrícola Unicamp (FEAGRI). Campinas: Unicamp, 2019.

PARETO, Vilfredo. Manual de economia política. Trad. João Guilherme Vargas Netto. São Paulo: Círculo do Livro Ltda., 1996.

PASQUALE, María Florencia. La función social de la propiedad en la obra de León Duguit: una re-lectura desde la perspectiva historiográfica. História Constitucional, n. 15. Oviedo: Ed. Universidad, 2014, p. 93-111.

RABBANI, Roberto Muhájir Rahnemay. O poluidor-pagador: uma nova análise de um princípio clássico. Revista Direito, Estado e Sociedade, n. 51, 2017.

SANTOS, Boaventura de Sousa. O direito dos oprimidos. Sociologia crítica do direito. São Paulo: Cortez, 2015.

SILVA, Solange Teles. Direito Fundamental ao Meio Ambiente Ecologicamente Equilibrado Avanços e Desafios. Cadernos do Programa de Pós-Graduação em Direito-PPGDir./UFRGS, n. 6, 2007.

SOUSA JÚNIOR, José Geraldo de. Direito como liberdade: o direito achado na rua. Porto Alegre: Fabris, 2011.

SUPREMO TRIBUNAL FEDERAL (STF). ADI 2.213-MC. Rel. min. Celso de Mello, julgamento em 4-4-2002, Plenário. DJ 23-4-2004, p. 3. Disponível em: $<$ http://redir.stf.jus.br/paginadorpub/paginador.jsp?docTP=AC\&docID=347486>. Acesso em: 17 de maio de 2019. 
SUPREMO TRIBUNAL FEDERAL (STF). MS 21.348. Rel. min. Celso de Mello, julgamento em 2-9-1993, Plenário, DJ de 8-10-1993. Disponível em: <<http://stf.jus.br>. Acesso em: 19 de maio de 2019.

SUPREMO TRIBUNAL FEDERAL (STF). MS 22.164. Rel. min. Celso de Mello, julgamento em 30-10-1995, Plenário, DJ de 17-11-1995. Disponível em: $<$ http://redir.stf.jus.br/paginadorpub/paginador.jsp?docTP=AC\&doclD=85691>. Acesso em: 17 de maio de 2019.

SUPREMO TRIBUNAL FEDERAL (STF). MS 25.793. Rel. min. Celso de Mello, decisão monocrática, julgamento em 5-11-2010. DJE 11-11-2010. Disponível em <http://stf.jus.br>. Acesso em: 17 de maio de 2019.

TRIBUNAL REGIONAL FEDERAL 1a REGIÃO (TRF-1). AC 001045394.2002.4.01.3500. Rel. Des. Daniel Paes Ribeiro, Trf1 - Sexta Turma, E-Djf1 27/06/2011, p. 035. Disponível em: <www.trf1.jus.br>. Acesso em: 18 de maio de 2019.

TRIBUNAL REGIONAL FEDERAL 2a REGIÃO (TRF-2). Apelação, Reexame Necessário 0000495-28.2007.4.02.5005. Relator: Guilherme Couto de Castro, julgamento 15/07/2013, DJ 24/07/2013. Disponível em: <www.trf2.jus.br>. Acesso em: 18 de maio de 2019.

VERACEL. Relatório de sustentabilidade 2019: ano base 2018. Disponível em: http://www.veracel.com.br/sobre-a-veracel/relatorio-de-sustentabilidade.

Acesso em: 08 de abril de 2020.

WOLKMER, Antônio Carlos. Direitos humanos: novas dimensões e novas fundamentações. Revista Direito em Debate, v. 11, n. 16-17, 2002.

WOLKMER, Antônio Carlos. Pluralismo jurídico: fundamentos de uma nova cultura no direito. 4. ed. São Paulo: Alfa-Ômega, 2015.

WOLKMER, Antonio Carlos; LEITE, José Rubens Morato. Os "novos" direitos no Brasil: natureza e perspectivas. São Paulo: Saraiva, 2003. 